\title{
ANALYSIS OF TRAVEL EXPERIENCE QUALITY AT CITY DESTINATIONS
}

\author{
Yeni Yuniawati, Oce Ridwanudin \\ Universitas Pendidikan Indonesia
}

\begin{abstract}
Bandung is one of the many destinations which could be categorised as urban tourismor urban travel destinations. These destinations have different characteristics compared to other types destinations, therefore the experience gained by tourists during visits would be different. This study aims to create a means of measuring the quality of the tourist experience viewed from three phases of travel experience, namely pre-travel phase measured by information search construct, planning, decision making; experiential phase, measured with product attributes, interaction and involvement constructs; and Recollection phase, measured by these constructs: meaning, satisfaction, storing, sharing, and Recollection. The research method is descriptive and verification using factor analysis data analysis techniques. Data were obtained through interviews and questionnaires to tourists who visit the city of Bandung as many as 200 people. The results showed that the proposed model is valid and reliable for measuring the travel experience.
\end{abstract}

Keywords: destination, urban tourism, tourist experience, travel experience.

\section{Introduction}

Tourism is growing in line with the rapid progress of time and changes in the characteristics of humans. The types of tourisms that are unknown a few decades ago, is now a tourist consumption in different parts of the world. One type of tourism that is rapidly growing is urban tourism or urban travel. City tour is defined as a set of attractiveness and tourism activities that are in a city and offered to visitors from outside the city (European Commission, 2000, in Cosma, 2012: 51). City tours arises because of the growing mobility of people requiring transit point as well as changes in behavior that lead to the city converted into a place of culture and relaxation.

Blank (1994) in Ismail et al. (2006: 3) mentions the five characteristics of the city that serves as a tourism destination, namely 1) a place that has a high population number that attract tourists to visit friends and relatives; 2) acts as the entrance and dissemination point tourists to other destinations; 3) became the center of business, industry, and economy; 4) The concentration of services such as education, government, health, and so forth; and 5) a place that offers a variety of cultural experiences, artistic, and recreational.

Edwards et al (2009: 7) state that: 
"Urban destinations are multifaceted environments. The concept of urban is both virtual and real in that it encompasses places where people, as they move around, find Themselves outside and inside structures. Therefore understanding the experience and behavior of visitors as they undertake activities in urban destinations is foundational to understanding the ensuing impacts that occur and how key elements of the industry can serve the visitors' needs and meet Reviews their expectations."

The above opinion states that when doing the movement in the city tourist destinations, travellers will interact with any existing structures in the city. Thus it is important to understand the experience and their behaviour in anticipation of possible impacts and formulate appropriate strategies to meet the needs of the tourist.

Experience and behaviour is integral in tourism activities carried out by tourists. Experience is basically the core of the tourism product (Prentice et al, 1998 in Morgan, et al, 2010: 11). Experience is also a crucial element in tourism so much research theme is mainly aimed at creating a tourism product attractive and different (Ellis \& Rossman, 2008; Li, 2000; Mossberg, 2007; Stamboulis \& Skayannis 2003 in Kastenholz \& Lima, 2011 : 63)

When visiting a destination, travelers will interact or make contact with the agent of tourism such as taxi drivers, hotel staff, waiters, and with elements of local attractions, such as museums, beaches, recreational parks, and so on. The overall impression of the contact and interaction will form a tourist experience that eventually build up the image of a destination in the minds of tourists after they visit. (Stanković, et.al, 2009: 23). Jennings (2006) stated that in tourism, a quality experience not only with the quality of service alone but many other related factors of which the interaction with the local population, motivation and perception of the destination, as well as the expectations of tourists itself will affect the perceived quality of obtained experience.

Various studies on tourists' quality of experience have been done, among them the quality of the tourist experience among students to distant places of residence of origin (Meng, 2006), the quality of the tourist experience in tourist destinations countryside (Loureiro, 2012), and the quality of the tourist experience in a suburb of Europe (Gymothy, 2000).

With the peculiarities of the destinations and segmentation of visiting tourists, then it is expected that what constitutes as quality experience in a city tourist destination would be different compared to other types. So based on the above background, the researchers found it necessary to analyse the measurement of the quality of tourist experience in Bandung as a tourist destination city by forming different measurement constructs compared to existing constructs. The constructs used in this research have been adjusted according to the characteristics of visiting tourists and the destination features itself. 


\section{Literature Review}

Tourism destination can be a particular resort or a city, or a region within the country, or a country as a whole, or an area larger than a country (Holloway: 2000 in Donelly, 2009: 14). While Cracolici and Nijkamp (2009: 339) defines the destination as the integration of all the elements (services, natural, cultural and artistic products) offered by an area that should be able to meet the needs of travellers. The opinion is in line with Camprubí, et al (2008) in Balan et al, (2009: 979), who states tourism destination as "a network of relations between different actors that, together, create the tourist product".

To benefit from the economic potential, a destination could do marketing activities that is described by the United Nations World Tourism Organization (2004: 10) as follows:

[destination marketing] covers all the activities and processes to bring buyers and sellers together; focuses on responding to consumer demands and competitive positioning; is a continuous coordinated set of activities associated with the efficient distribution of products to high potential markets; and Involves making decisions about the product, branding, price, market segmentation, promotion and distribution."

In practice, marketing and destination management are generally influenced by various factors, such as social, political, legal, geophysical, technology, economics, competitors and consumers. Kotler et al. (1999) in Machlouzarides (2009: 163) highlighted five main elements in destination marketing, namely 1) tourists; 2) the destination itself; 3) tourism suppliers; 4) the local population; and $5)$ coordination between the public and private sectors.

Pizam (2011: 3) states that "Destinations must design, promote, coordinate a satisfying total visitor experience that maximizes the economic contributions to the destinations and one that Stimulates return intention and referral behaviour".

Experience is something that is personal and reflects the involvement of customers in different stages, namely the rational, emotional, sensorial, physical, and spiritual. (Gentile, Spiller, and Noci 2007 in Verhoef, et. Al, 2007:32). Experience is formed in a process where interaction occurs in a particular setting between an individual with other parties, including those who offer economy exchange (Boswijk, et al 2007: 144), and for the tourism industry experience is "the core of tourism product" (Prentice et al, 1998 in Morgan, et al, 2010: 11).

When visiting a destination, travellers will interact or make contact with the actors of tourism such as taxi drivers, hotel staff, waiters, and with elements of local attractions, such as museums, beaches, recreational parks, and so on. The overall impression of the contact and interaction will form the whole travel experience to build the image of a destination in the minds of tourists after they visit. (Stanković, et.al, 2009: 23). Thus, the tourist experience (tourism experience) is something that is influenced by a variety of activities, wherein each activity was carried out by different individuals or businesses (Gyimothy: 2000). 
Meng (2006) defined tourism experience as the perception of tourists regarding the level of enjoyment they experience relating to products and services that are consumed in each phase in the whole tourism process. While Oh et.al (2007: 120) argues that the travel experience is enjoyable, engaging, memorable encounters for those consuming these events.

The quality of the tourist experience is defined as the perception of tourists to the quality of products and services that are consumed during the tour (Jennings \& Nickerson, 2006). It has broad functions and meanings, which are described explicitly, implicitly, and tactical by industry, business, government, tourists, community and academia (Jennings, 2006: 5). From the standpoint of tourists, the quality of the experience is very influential on their perceptions regarding the competitiveness of destinations, imagery, decision whether to visit and post-visit behaviour (Meng, 2006).

In the study of tourism, quality has been associated with service quality, quality assurance, perceptions of quality at an individual / business / community level as well as to differences in the products and markets. Further Jennings argued that the most frequent and most widely performed, quality is defined as a form of demand and consumer expectations along with the received benefits.

Jennings and Nickerson (2006) in Meng (2006: 18) argues that the Quality of Tourism Experience is "The tourists' perception of the degree of quality of their tourism experience related to the product and services received during different phases of the entire vacation process". Based on such understanding, it can be said that in order to measure the quality of their experience of tourists at a tourist destination, it must be done in each phase of the overall process that tourists do

Killion, Craig-Smith and French (1994) in Jennings and Nickerson (2006: 8) develop the model of tourist experience that consists of three phases in the form of liner with the concept first experience cue or inform subsequent experience. The three phases consists of anticipatory phase, experiential phase, and reflective phase. The model looks like in the picture below.

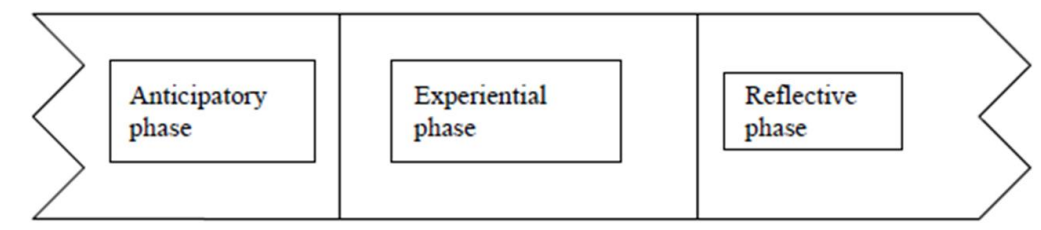

Figure 1.3 The three phases of the vacation experience (Craig-Smith and French, 1994).

Source: Jennings and Nickerson (2006: 9)

\section{Figure 1}

Three Phase of Tourists' Experience Rating When Travelling

\section{Anticipatory Phase}

Anticipatory or pre-travel phase is the phase where the tourists do search activity information that would assist in decision making. Travelers need a certain amount 
of information about destinations and tourism products before traveling (Dellarocas and Narayan, 2006). According to Burgess et al (2009), tourists use different strategies on where to get information about the products and services they want to buy. Products that have a quality experience such as tourism cannot be disconnected easily and tourists therefore be highly dependent on the recommendations given. Thus, the advice from other travellers who have been to have an enormous influence (Crotts, 1999). Pan and Fesenmaier (2006) states that the internet has become an important source for travellers in search activity information.

Anticipatory phase can be described as a period that is used for planning and arranging vacation and be the deciding factor of the overall tourist experience. While Candela and Figini (2012: 21) states that the anticipatory phase consists of decision-making and planning trips. Meanwhile, according to Meng (2006: 33) anticipatory / pre travel consists of a purchase decision, planning and anticipation.

\section{Experiential Phase}

This phase is called the phase of on-site experience, which is the phase where tourists feel for themselves the quality of products and services that are at a destination. In this phase, tourists make contact with the social, cultural, environmental and tourist destinations thus forming experience (Pearce, 2006: 20). Other than through interaction with all three of these factors, the experience of a tourist destination can also be influenced by the attributes of the destination itself, which consisted of attractions, accessibility, amenities, ancillary services, and accommodation (Baker \& Crompton, 2000). In terms of engagement, Pine and Gilmore (1998) argue that in a destination, tourists feel different experience depending on their engagement with its environment, namely entertainment, education, aesthetic and escapist.

\section{Recollection Phase}

Reflective phase is the phase in which the tourists have activity in the visited destinations and have an assessment of the quality of experience perceived. In this phase the tourists feel satisfaction and significance of tourism activities they experienced (Korner: 15). While according to the Laws (1995) in Meng (2006: 14 ) in this phase tourists also do recollection or recall their tourist trip.

Aho (2001) in Ritchie and Hudson (2009: 132) adds that tourists store (storing) a memento in the form of photos or souvenirs, in addition to the era in which the Internet plays an important role in human life tourists also make sharing or share via media social (Buhalis, 2003)

Based on the literature review, the constructs that represents tourist experience quality are as follow. 
Table 1

Builders Constructs Quality Travel Experience

\begin{tabular}{|c|c|c|}
\hline Phase & Construct & Indicator \\
\hline Anticipatory & $\begin{array}{l}\text { Information search } \\
\text { Dellarocas and Narayan (2006), } \\
\text { Burgess, et al (2009), Crotts (1999), Pan } \\
\text { \& Fesenmaier (2006) } \\
\text { Korner (2010), } \\
\text { Planning } \\
\text { Meng (2006), Candela and Figini (2012) } \\
\text { Decision making }\end{array}$ & $\begin{array}{l}\text { Web, WOM, other media } \\
\text { Time, activity } \\
\text { Route \& facility }\end{array}$ \\
\hline Experiential / On Site & $\begin{array}{l}\text { Interaction } \\
\text { Pearce (2006) } \\
\text { Attribute destinations } \\
\text { Baker \& Crompton (2000), Bramwell } \\
\text { (1998) } \\
\text { Involvement } \\
\text { Pine \& Gilmore (1998) }\end{array}$ & $\begin{array}{l}\text { Social, cultural, environmental } \\
\text { Attraction, amenities, ancillary, } \\
\text { activities, accessibility } \\
\text { Entertainment, educational, aesthetic, } \\
\text { escapist }\end{array}$ \\
\hline Reflective & $\begin{array}{l}\text { Satisfaction \& Meanings } \\
\text { Korner (2010) } \\
\text { Recollection } \\
\text { Laws (1995) in Meng (2006) } \\
\text { Aho (2001) in Ritchie and Hudson } \\
(2009) \\
\text { Storing } \\
\text { Aho (2001) in Ritchie and Hudson } \\
(2009) \\
\text { Sharing } \\
\text { Buhalis } 2003\end{array}$ & $\begin{array}{l}\text { Personal, social } \\
\text { Product, service } \\
\text { Feeling, frequency } \\
\text { Photo, souvenir } \\
\text { Narrative, social media }\end{array}$ \\
\hline
\end{tabular}

\section{Methodology}

The research method is descriptive and verification using factor analysis data analysis techniques. Data were obtained through interviews and questionnaires to tourists who visit the city of Bandung as many as 200 people.

\section{Results and Discussion}

Based on the results of data processing, the three coefficient estimates from the three dimensions and eleven indicators give the coefficient weighting factor above 0.50. This means that the dimensions and indicators used to measure the construct validity of quality experience were able to measure it. In addition, the reliability of construct dimensions and indicators values, were value above 0.70 . This means that the composite dimensions and indicators on the proposed model have adequate reliability in estimating quality experience.

In addition, it can be concluded that the measurement model as a unidimensional construct quality experience, valid and reliable can be explained 
by the dimensions of anticipatory phase, experience phase, and reflective phase. The validity and unidimensionality of the three dimensions as valid and reliable indicators can be explained by the information search, planning, decision making, product attributes, interaction, involvement, meaning, satisfaction, storing, sharing and recollection.

When sorted according to the estimates of validity and reliability, anticipatory phase (X1) has the greatest reliability and validity in forming construct quality experience, respectively 0.9625 and 0.9263. Furthermore, experience phase (X2) has the second largest of validity and reliability that is equal to 0.8666 and 0.751 and reflective phase (X3) have the smallest estimate in shaping the construct of quality experience in which to estimate the validity and reliability of 0.7144 and 0.5104 . As for the indicators in the form dimensions anticipatory phase, decision making is an indicator that has the greatest validity and reliability estimates each by 0.7373 and 0.5436 . The smallest estimate obtained by the information search; 0.5852 and 0.3424 .

Product attribute is an indicator that received the greatest reliability and validity estimates in forming phase-dimensional experience of 0.7926 and 0.6283 . While involvement is smallest indicator in shaping the experience phase, with the estimated validity and reliability of 0.518 and 0.3502 . In the forming of reflective phase dimension, the largest indicator is obtained by recollection with estimated values of 0.8584 and 0.7369 . While satisfaction is the smallest forming of reflective phase, with the validity and reliability being 0.5370 and 0.2884 respectively.

\section{Conclusion}

The results showed that the proposed model is valid and reliable for measuring the travel experience. It can be concluded that the measurement model as a unidimensional construct quality experience, valid and reliable can be explained by the dimensions of anticipatory phase, experience phase, and reflective phase. The validity and unidimensionality of the three dimensions as valid and reliable indicators can be explained by the information search, planning, decision making, product attributes, interaction, involvement, meaning, satisfaction, storing, sharing and recollection.

\section{References}

Cracolici, M.F., \& Nijkamp, P. (2005). Attractiveness and Effectiveness of Competing Tourist Areas: A Study on Italian Provinces. File URL: ftp://zappa.ubvu.vu.nl/20050009.pdf. Dimuat dalam Jurnal Tourism Management 2009 30(3), 336-344.

Donelly, Martina. (2009). Building Customer Loyalty: A Customer Based Approach in a Tourism Context. Master Thesis Waterford Institute of Technology 
Balan, D., Balaure, V., \& Veghes, C. (2009). Travel and tourism competitiveness of the world's top tourism destinations: An exploratory Assessment. Annales Universitatis Apulensis series Oeconomica, 11, (2).

Kotler, Philip \& Gray Armstrong. (2012). Principles of Marketing. $5^{\text {th }}$ ed. U.S.A. Pearson Education, Inc.

Machlouzarides, Haris. (2009). Improving the Deployment Model of Modern Electronic Marketing Methods for the Cyprus Tourism Organisation. Dissertation

Verhoef, Peter C. 2009. Customer Experience Creation: Determinants, Dynamics and Management Strategies. Journal of Retailing 85 (1, 2009) 31-41

Wang, Youcheng and Abraham Pizam. (2011). Destination Marketing and Management: Theories and Applications. CAB International: Oxforshire

Morgan, Michael, Peter Lugosi, and J. R. Brent Ritchie. (2010). The Tourism and Leisure Experience: Consumer and Managerial Perspectives. Chanel View Publications: Bristol

Stanković, Ljiljana, dan Jelena Petrović. (2007). Marketing Of Tourism Destination Of Nǐ̌, , Facta Universitatis Series: Economics and Organization Vol. 4, No 1, 2007, pp. 9 - 20

Meng, Fang (2006). An Examination of Destination Competitiveness from the Tourists' Perspective: The Relationship between Quality of Tourism Experience and Perceived Destination Competitiveness. Thesis: Virginia Polytechnic Institute and State University

Oh, Haemoon, Ann Marie Fiore, and Miyoung Jeoung. (2007). Measuring Experience Economy Concepts: Tourism Applications. Journal of Travel Research 2007 46: 119-132

Gyimóthy, Szilvia. (2000). The Quality of Visitor Experience. A Case Study in Peripheral Areas of Europe. PhD thesis. Anglia Polytechnic University, Bornhomls, Denmark

Jennings, G. \& Nickerson, N. P. (2006). Quality Tourism Experience. Burlington, MA:

Jennings, G. (2006). Perspectives on quality tourism experiences: an introduction. In $\mathrm{G}$.

Pike,Steven.
(2008).

AnIntegratedMarketing Communication Heinemann. Elsevier Ltd.
DestinationMarketing: Approach.Butterworth-

Pine, J., \& Gilmore, J. (1999). The experience economy: Work is theatre and every business is a stage. Boston: Harvard Business School Press. 